\title{
Temporal trends in CD4-positive T-cell counts among AIDS patients in Tianjin, China: 2005-2016
}

\author{
Jing Qian ${ }^{1,2, *}$, Defa Zhang ${ }^{1,2, *}$, Liying Gao ${ }^{1,2}$, Aiping $\mathbf{Y u}_{\mathbf{u}^{1,2}}$, Chunting Qiu ${ }^{1}$, Lei $\mathbf{L i}^{1}$, \\ Fangfang $\mathrm{Yu}^{1}$, Yue $\mathrm{Wu}^{1}{ }^{1}$, Wei You ${ }^{1,2}$, Yanyun Guo ${ }^{1}$, Jinghua Wang ${ }^{3,4,5}$, Xianjia \\ Ning $^{3,4,5}$, Wei Lu ${ }^{1}$ and Ping $\mathrm{Ma}^{1,2}$ \\ ${ }^{1}$ Department of Infectious Disease, Tianjin Second People's Hospital, Tianjin 300192, China \\ ${ }^{2}$ Association of Tianjin STD and AIDS Prevention and Treatment, Tianjin 300050,China \\ ${ }^{3}$ Center of Epidemiology and Department of Neurology, Tianjin Medical University General Hospital, Tianjin 300052, China \\ ${ }^{4}$ Tianjin Neurological Institute, Key Laboratory of Post-Neuroinjury Neuro-repair and Regeneration in Central Nervous \\ System, Ministry of Education and Tianjin City, Tianjin 300052, China \\ ${ }^{5}$ Department of Epidemiology, Tianjin Neurological Institute, Tianjin 300052, China \\ *These authors contributed equally to this work
}

Correspondence to: Ping Ma, email: mapingtianjin@163.com

Wei Lu, email: luweidr@126.com

Keywords: AIDS; epidemiology; trends; CD4 cell count; china

Received: September 22, $2017 \quad$ Accepted: December 05, $2017 \quad$ Published: January 12, 2018

Copyright: Qian et al. This is an open-access article distributed under the terms of the Creative Commons Attribution License 3.0 (CC BY 3.0), which permits unrestricted use, distribution, and reproduction in any medium, provided the original author and source are credited.

\section{ABSTRACT}

The purpose of this study was to assess trends in CD4 cell counts among patients with AIDS living in Tianjin, China. All patients with AIDS who were registered in Tianjin from 2005 to $\mathbf{2 0 1 6}$ were recruited to this study. Information on demographic characteristics and clinical features was recorded. Mean CD4 cell counts and the frequency of CD4 cell counts $<200$ were assessed by age, transmission route, and education level. Men accounted for $93.6 \%$ of cases ( 2867 cases), and women accounted for $6.4 \%$ (195 cases). The median CD4 cell counts significantly increased for each age group over the 12-yearstudy period overall; in particular, median counts increased by $67.4 \%$ in patients aged $<25$ years. Similar trends were found in patients infected through homosexual transmission and those with an education level of $\geq 13$ years. Compared to that in 2005-2010, the prevalence of low CD4 levels $(<200)$ was significantly decreased in 2016, especially for patients aged 25-29 years, those infected through homosexual transmission, and those with $\geq 13$ years of education. These findings suggest that the burden of AIDS will continue to increase in Tianjin. It is crucial to begin managing AIDS patients who still have high CD4 cell counts in order to ensure effective therapy. At the same time, education of high-risk populations should begin in high school.

\section{INTRODUCTION}

The global incidence of human immunodeficiency virus (HIV) reached its peak in 1997. The annual incidence has stayed relatively constant since 2005 , following a period of rapid decline (by 4.8\% per year) between 1997 and 2005 [1]. However, the age-standardized prevalence of HIV/AIDS increased by $4 \%$ (ranging from $3 \%$ to $5 \%$ ) annually during 2005 to 2015 , andmortality increased by $8 \%$ (ranging from $7 \%$ to $9 \%$ ) in China [1]. Acquired immune deficiency syndrome (AIDS) has recently become the leading cause of death in China, and the number of AIDS-related deaths is significantly higher than that due to any other infectious disease [2].

The cluster of differentiation 4-positive T-cell (CD4) count is a strong predictor of progression to AIDS and is used to monitor the efficacy of antiretroviral therapy (ART). CD4 counts are inversely associated with the replication of HIV. Low CD4 counts have been shown to predict a greater risk of death and the development 
of opportunistic infections [3-7]. Over the past decade, the widespread use of ART has played an important role in people living with HIV/AIDS by suppressing viral replication and preventing decreases in CD4 levels [8-11].

In 2015, two large randomized trials confirmed the benefit of starting ART at any time, without respect to the CD4 cell count. Thus, the World Health Organization (WHO) issued updated guidelines and recommended ART for all HIV-infected adults, regardless of CD4 counts [1216]. The new guidelines resulted in a higher frequency of individuals starting ART with higher CD4 counts, in addition to lower adherence rates [17, 18]. Moreover, trends in CD4 cell counts according to age, education level, and transmission route are unclear.

Therefore, the aim of this study was to assess trends in CD4 cell counts according to age, education level, and transmission route from 2005 to 2016 in Tianjin, China.

\section{RESULTS}

\section{Patient characteristics}

A total of 3063 AIDS patients were registered in the Tianjin Second People's Hospital from January 2005 to December 2016. Ultimately, 3062 cases were evaluated in this study, after excluding 1 case with vertical transmission.

Most of the patients in this study were men (accounting for $93.6 \%$ of the sample). Men were more likely than women to be younger, to have higher education, and to have been infected through homosexual transmission. Moreover, the median CD4 cell counts were higher in male patients than in female patients, but there was no difference in the frequency of severe suppression (Table 1).

\section{Trends in CD4 cell counts by age}

Table 2 shows that medianCD4 cell counts significantly increased for each age group over the 12 -yearstudy period overall, especially in patients aged $<30$ years. Median CD4 cell counts increased by $67.4 \%$ for patients aged $<25$ years and by $45.9 \%$ for patients aged $<30$ years. The rates of increase in median cell counts were $29.3 \%$ for people aged $30-34$ years, $27.1 \%$ for those aged 35-39 years, $4.2 \%$ for those aged $40-44$ years, $33.8 \%$ for those aged $45-49$ years, and $10.9 \%$ for those aged $\geq 50$ years, respectively. Simultaneously, the rates of severe suppression decreased remarkably for all age groups, with decreases of $81.9 \%, 44.3 \%, 54.4 \%, 47.4 \%, 23.6 \%, 26.9 \%$, and $13.7 \%$ for the age groups above, respectively.

\section{Trends in CD4 cell counts by transmission route}

MedianCD4 cell counts increased significantly among patients infected through sexual transmission over the 12-yearstudy period overall. Median CD4 cell counts increased by $52.9 \%$ for patients infected by homosexual transmission and by $38.0 \%$ for those infected by heterosexual transmission $(P<0.001)$. Simultaneously, the rates of severe suppression decreased remarkably in the homosexual and heterosexual transmission groups, by $60.5 \%$ and $33.3 \%$, respectively (Table 3 ).

\section{Trends in CD4 cell counts by education level}

Table 4 shows that CD4 counts on admission increased significantly over time for all education groups $(P<0.001)$, with increases of $59 \%, 65.6 \%, 43.2 \%$, and $67.3 \%$ for those with $<6$ years, $7-9$ years, $10-12$ years, and $\geq 13$ years of education, respectively. The frequency of patients with CD4 counts $<200$ was reduced among the 7-9 years, 10-12 years education, and $\geq 13$ years of education groups (all $P<0.001$ ). Compared to the frequency observed before 2011, the frequency of low CD4 counts $(<200)$ decreased by $47.9 \%$ overall, by $54.9 \%$ for those with $7-9$ years of education, by $32.3 \%$ for those with $10-12$ years of education, and by $56.0 \%$ for those with $\geq 13$ years of education. There were no significant differences among patients with an education level of $\leq 6$ years.

\section{DISCUSSION}

This is the first study to report trends in CD4 cell counts among AIDS patients in Tianjin, China. The findings in this study indicate that average CD4 cell counts increased generally over time for all age groups, education groups, and sexual transmission groups. The greatest increase was observed in patients aged 25-29 years, those infected through homosexual transmission, and those with $\geq 13$ years of education. The frequency of CD4 cell counts $<200$ significantly decreased over time, particularly among those aged 25-29 years (by 54.4\%), those infected through homosexual transmission (by $67.3 \%$ ), and those with $\geq 13$ years of education (by $56.0 \%$ ).

CD4 cell counts are strong predictors of progression to AIDS, as well as a means of monitoring ART. Low CD4 cell counts are associated with a greater risk of patients developing opportunistic infections, which may then progress to advanced diseases and death $[4,5]$.

A recent report from China demonstrated that among 388,496 newly identified HIV cases, the median baseline CD4 count increased from 221 (IQR: 63-410) in 2006 to 314 (IQR: 159-460) in 2012. The percentage of individuals with baseline CD4 cell counts indicating advanced disease $(200$ cells $/ \mu \mathrm{L})$ decreased from $46.9 \%$ in 2006 to $30.7 \%$ in 2012 [19]. Similar findings were observed in the present study; the median baseline CD4 count in AIDS patients increased from 212 counts/ $\mu \mathrm{L}$ to 303 counts/ $\mu \mathrm{L}$ during 2005 to 2016.

The WHO issued updated guidelines in 2015 recommending that ART should be started in all HIV- 
Table 1: The demographical characteristics of participants in this study

\begin{tabular}{|c|c|c|c|c|}
\hline Categories & Men & Women & Total & $P$ \\
\hline Number, $n(\%)$ & $2867(93.6)$ & $195(6.4)$ & 3062 & - \\
\hline Age, year, means (SD) & 37.84 (11.79) & $43.27(12.61)$ & $38.19(11.91)$ & $<0.001$ \\
\hline Age group, $n(\%)$ & & & & $<0.001$ \\
\hline$<20$ & $27(0.9)$ & $3(1.5)$ & $30(1.0)$ & \\
\hline $20 \sim$ & $294(10.3)$ & $7(3.6)$ & $301(9.8)$ & \\
\hline $25 \sim$ & $560(19.5)$ & $20(10.3)$ & $580(18.9)$ & \\
\hline $30 \sim$ & $553(19.3)$ & $21(10.8)$ & $574(18.7)$ & \\
\hline $35 \sim$ & $338(11.8)$ & $35(17.9)$ & $373(12.2)$ & \\
\hline $40 \sim$ & $283(9.9)$ & $23(11.8)$ & $306(10.0)$ & \\
\hline $45 \sim$ & $286(10.0)$ & $32(16.4)$ & $318(10.4)$ & \\
\hline$\geq 50$ & $526(18.3)$ & $54(27.7)$ & $580(18.9)$ & \\
\hline Education group, $n(\%)$ & & & & $<0.001$ \\
\hline$\leq 6$ years & $106(3.7)$ & $32(16.4)$ & $138(4.5)$ & \\
\hline 7 9 years & $634(22.1)$ & $76(39.0)$ & $710(23.2)$ & \\
\hline $10 \sim 12$ years & $803(28.0)$ & $60(30.8)$ & $863(28.2)$ & \\
\hline$\geq 13$ years & $1324(46.2)$ & $27(13.8)$ & $1351(44.1)$ & \\
\hline Route of infection & & & & $<0.001$ \\
\hline Transfusion/Blood sample & $37(1.3)$ & $5(2.6)$ & $42(1.4)$ & \\
\hline Intravenous drug using & $116(4.0)$ & $18(9.2)$ & $134(4.4)$ & \\
\hline Homosexual & $1957(68.3)$ & $2(1.0)$ & $1959(64.0)$ & \\
\hline Heterosexual & $472(16.5)$ & $139(71.3)$ & $611(20.0)$ & \\
\hline Unknown & $285(9.9)$ & $31(15.9)$ & $316(10.3)$ & \\
\hline $\mathrm{CD} 4$, counts/ $\mu \mathrm{L}$, median (IQR) & $250(220)$ & $224.5(192)$ & 248 (219) & 0.030 \\
\hline CD4 groups: & & & & 0.052 \\
\hline$\geq 500$ counts $/ \mu \mathrm{L}$ & $188(6.7)$ & $14(7.4)$ & $202(6.7)$ & \\
\hline $350 \sim 499$ counts $/ \mu \mathrm{L}$ & $488(17.3)$ & $16(8.4)$ & $504(16.7)$ & \\
\hline $200 \sim 349$ counts $/ \mu \mathrm{L}$ & $1060(37.5)$ & $76(40.0)$ & $1136(37.7)$ & \\
\hline$<200$ counts $/ \mu \mathrm{L}$ & $1087(38.5)$ & $84(44.2)$ & $1171(38.9)$ & \\
\hline
\end{tabular}

infected adults regardless of CD4 count or WHO stage; these guidelines were based on the results of two large randomized trials that demonstrated the clinical benefit of starting ART at any CD4 cell count [12-16]. Accordingly, the mean CD4 counts among patients starting ART increased following the release of these updated guidelines. Many studies have demonstrated that the effectiveness of ART may be associated with factors related to treatment adherence, habits, infections unrelated to HIV, cancer, the use of immunosuppressive drugs, as well as socio-economic and psychosocial factors and access to healthcare $[4,5,11]$. Younger age, lower education, and lower income were all shown to be associated with worse therapeutic and immune responses due to the low frequency of adherence and poor access to healthcare services [20-22]. However, previous studies have also demonstrated that decreased adherence was associated with higher baseline CD4 counts [23-29].
CD4-positive $\mathrm{T}$ cells orchestrate host immunity by identifying different cell lineages or subsets that recruit and activate other immune cells [30, 31]. In HIV infection, however, CD4-positive $\mathrm{T}$ cells are also the predominant target of the virus. A hallmark for untreated HIV disease is the progressive depletion of CD4-positive $\mathrm{T}$ cells, leading to impairment of cellular immunity and enhanced susceptibility to opportunistic infections, which defines AIDS [32-34]. Immunological suppression and disturbances caused by HIV infection contribute to the decline in CD4 cell counts and predict both morbidity and mortality from AIDS [35, 36]. Moreover, a majority of studies have shown evidence for an increased risk for progression to AIDS or death among those with low CD4 cell counts [37-43].

However, there has been no consensus on the definition of an adequate CD4 response until now. Some researchers defined an adequate response as achieving an 
Table 2: Trends in levels of CD4 of AIDS by age groups during 2005 to 2016 in Tianjin, China (years)

\begin{tabular}{|c|c|c|c|c|c|c|c|}
\hline Year & $<25$ years & 25 years $\sim$ & 30 years $\sim$ & 35 years $\sim$ & 40 years $\sim$ & 45 years $\sim$ & $\geq 50$ years \\
\hline \multicolumn{8}{|c|}{$\mathrm{CD} 4$, counts $/ \mu \mathrm{L}$, means $(\mathrm{SD})$ : } \\
\hline$<2011$ & - & $236.75(56.34)$ & $246.58(229.77)$ & $225.57(109.35)$ & $226.53(117.39)$ & $199.87(97.17)$ & $196.12(110.80)$ \\
\hline 2011 & $204.29(90.72)$ & $198.93(123.31)$ & $211.46(136.27)$ & $183.55(123.47)$ & $157.25(113.58)$ & $185.52(151.78)$ & $165.00(111.43)$ \\
\hline 2012 & $221.29(120.65)$ & $204.65(116.67)$ & $242.69(120.83)$ & $205.00(115.90)$ & $177.80(118.53)$ & 210.64 (139.97) & $149.62(109.23)$ \\
\hline 2013 & $201.58(113.36)$ & $226.31(125.52)$ & $211.39(136.27)$ & $236.64(112.87)$ & $187.30(128.61)$ & $170.36(118.41)$ & 195.69 (117.63) \\
\hline 2014 & $310.87(147.43)$ & $292.14(143.17)$ & $257.77(141.96)$ & $236.27(179.12)$ & $246.13(173.65)$ & $250.41(199.88)$ & 204.49 (147.97) \\
\hline 2015 & $333.67(144.66)$ & $315.47(162.13)$ & $285.09(165.26)$ & $262.96(161.34)$ & $249.02(141.38)$ & $238.34(187.22)$ & $200.51(183.21)$ \\
\hline 2016 & $341.93(175.00)$ & $345.33(198.11)$ & $318.81(198.41)$ & $286.69(167.46)$ & $235.95(189.45)$ & 267.35 (224.44) & $217.51(175.44)$ \\
\hline Overall & $323.42(160.59)$ & $299.36(169.53)$ & $268.48(165.09)$ & $240.34(153.16)$ & $215.73(152.09)$ & $218.87(177.27)$ & $189.83(146.63)$ \\
\hline$P$ & 0.006 & $<0.001$ & $<0.001$ & 0.008 & 0.038 & 0.045 & 0.039 \\
\hline \multicolumn{8}{|c|}{ Proportion of $\mathrm{CD} 4<200$ counts $/ \mu \mathrm{L}$ : } \\
\hline$<2011$ & $1(100)$ & $2(40.0)$ & $14(58.3)$ & $18(56.3)$ & $23(62.2)$ & $25(65.8)$ & $42(59.2)$ \\
\hline 2011 & $2(40.0)$ & $5(35.7)$ & $16(43.2)$ & $17(51.5)$ & $15(62.5)$ & $16(55.2)$ & $34(60.7)$ \\
\hline 2012 & $3(42.9)$ & $24(46.2)$ & $16(38.1)$ & $16(50.0)$ & $15(50.0)$ & $16(48.5)$ & $35(58.3)$ \\
\hline 2013 & $6(50.0)$ & $16(38.1)$ & $24(42.9)$ & $16(34.0)$ & $19(57.6)$ & $19(52.8)$ & $39(52.0)$ \\
\hline 2014 & $10(18.2)$ & $34(28.6)$ & $42(33.1)$ & $29(47.5)$ & $22(41.5)$ & $25(43.9)$ & $51(51.0)$ \\
\hline 2015 & $16(15.5)$ & $40(24.2)$ & $38(26.4)$ & $32(34.4)$ & $20(33.3)$ & $29(45.3)$ & $65(56.5)$ \\
\hline 2016 & $26(18.1)$ & $39(22.3)$ & $37(26.6)$ & $21(29.6)$ & $28(47.5)$ & $25(48.1)$ & $48(51.1)$ \\
\hline Overall & 64 (19.6) & $160(28.0)$ & $187(32.9)$ & $149(40.4)$ & $142(48.0)$ & $155(50.2)$ & $314(55.0)$ \\
\hline$P$ & $<0.001$ & $<0.001$ & $<0.001$ & $<0.001$ & $<0.001$ & $<0.001$ & $<0.001$ \\
\hline
\end{tabular}

increase in CD4 count after 6 months on ART, reaching a threshold of 200 cells/ $\mu \mathrm{L}$. An absolute CD4 count at 6 months of $<200$ cells $/ \mu \mathrm{L}$ was reported to be the strongest predictor of progression to newly developed AIDS and death [37].

In Korea, patients with low CD4 cell counts $(\leq 200$ cells $/ \mu \mathrm{L})$ at diagnosis $(31-51 \%)$ and those being treated with initiation of HAART accounted for the majority of patients (30-65\%) over the study's3-year time interval, and the proportion increased until 2010-2012 [44]. In northwest Spain from 2004-2013, 53.1\% of newly infected HIV patients had low CD4 cell counts $(<350$ cells $/ \mu \mathrm{L}$ ) [45]. In the United Kingdom, $49 \%$ of newly infected HIV patients in 2011 were diagnosed withCD4 cell counts $<350$ cells $/ \mathrm{mL}^{3}[43]$. Furthermore, about $72 \%$ of patients in China were diagnosed withCD4 cell counts $\leq 200$ cells/mL during2009-2010 [46].

In the present study, we found an upward trend in average CD4 cell counts and a downward trend in the frequency of severe suppression over the 12-year study period in Tianjin, China. The greatest changes were observed for those aged 25-29 years, those infected through homosexual transmission, and those with $\geq 13$ years of education. The upward trend in CD4 cell counts suggests that increasingly more individuals began ART therapy with higher CD4 cell counts, which may result in fewer deaths in the future in Tianjin, China. Simultaneously, the lower adherence rate to ART among patients with higher CD4 cell counts may contribute to advancing disease progression.
Moreover, the frequency of CD4 cell counts $<200$ decreased significantly over time, particularly among those aged 25-29 years, those infected through homosexual transmission, and those with $\geq 13$ years of education. These findings indicate that more mild AIDS cases were diagnosed earlier, especially among those with high education levels in Tianjin. These findings suggest that complications could be reduced, life expectancy could be increased, and quality of life could be significantly improved among AIDS patients. These benefits are the result of improved health education and AIDS knowledge. However, it is vital to increase capital investment for providing the free ART. At the same time, new policies should be made that address the management of AIDS in patients with high CD4 cell counts and poor treatment adherence.

There were several limitations in the present study. First, data were obtained from a single center and therefore may not represent the general Chinese population. However, Tianjin is in a developed area in China, and trends in the epidemiology of AIDS in this area may represent trends in other economically developed areas in China. Second, information on marital status and spouses were not assessed in this study due to privacy concerns. Finally, the surveillance of individuals living with HIV/AIDS early in the study period may have been under-rated. However, Tianjin Second People's Hospital was the only qualified sentinel hospital in Tianjin, China during the study period. All data analyzed in this study were obtained from an official registry and are considered 
Table 3: Trends in levels of CD4 of AIDS by transmission routes during 2005 to 2016 in Tianjin, China

\begin{tabular}{|c|c|c|c|c|c|c|}
\hline Year & Total & Transfusion & IDU & Homosexual & Heterosexual & Unknown \\
\hline \multicolumn{7}{|c|}{$\mathrm{CD} 4$, counts $/ \mu \mathrm{L}$, means (SD): } \\
\hline$<2011$ & $212.57(127.61)$ & 280.00 & $238.17(111.22)$ & $214.87(138.33)$ & $197.58(117.60)$ & $288.50(58.69)$ \\
\hline 2011 & $182.22(119.69)$ & & $254.93(168.98)$ & $181.50(111.78)$ & $169.53(116.57)$ & $115.25(118.38)$ \\
\hline 2012 & $196.12(121.81)$ & & $214.86(156.77)$ & $194.39(110.08)$ & $192.91(138.34)$ & $234.00(213.51)$ \\
\hline 2013 & $205.56(123.38)$ & $278.50(167.22)$ & $211.14(103.98)$ & $200.67(116.45)$ & $211.54(145.63)$ & $202.96(120.06)$ \\
\hline 2014 & $256.61(160.16)$ & $210.75(164.46)$ & $219.83(139.12)$ & $272.73(163.76)$ & $234.49(144.46)$ & $219.27(159.84)$ \\
\hline 2015 & $275.78(169.62)$ & $183.75(128.51)$ & $251.39(92.18)$ & $300.94(166.44)$ & $246.34(178.23)$ & $184.66(150.69)$ \\
\hline 2016 & 303.28 (194.47) & $226.00(155.84)$ & 192.80 (111.94) & $328.59(188.94)$ & $272.59(195.60)$ & $234.31(204.02)$ \\
\hline Overall & $251.68(166.78)$ & $209.44(143.13)$ & $217.07(125.91)$ & $269.13(168.26)$ & $227.28(162.55)$ & $209.76(167.79)$ \\
\hline$P$ & $<0.001$ & 0.611 & 0.625 & $<0.001$ & 0.001 & 0.373 \\
\hline \multicolumn{7}{|c|}{ Proportion of $\mathrm{CD} 4<200$ counts $/ \mu \mathrm{L}$ : } \\
\hline$<2011$ & $125(58.4)$ & $2(50.0)$ & $11(55.0)$ & $70(63.6)$ & $33(55.0)$ & $9(64.3)$ \\
\hline 2011 & $105(51.5)$ & & $5(33.3)$ & $66(54.5)$ & $32(55.2)$ & $2(50.0)$ \\
\hline 2012 & $125(46.8)$ & & $7(50.0)$ & $86(47.8)$ & $27(48.2)$ & $5(83.3)$ \\
\hline 2013 & $139(43.6)$ & $3(50.0)$ & $9(40.9)$ & $72(44.2)$ & $32(52.5)$ & $23(46.9)$ \\
\hline 2014 & $213(36.9)$ & $3(37.5)$ & $15(48.4)$ & $121(32.4)$ & $42(45.2)$ & $32(48.5)$ \\
\hline 2015 & $240(32.2)$ & $9(56.3)$ & $5(27.8)$ & $129(26.0)$ & $58(40.6)$ & $39(55.7)$ \\
\hline 2016 & $224(30.4)$ & $3(42.9)$ & $6(60.0)$ & $123(25.1)$ & $47(36.7)$ & $4.5(45.5)$ \\
\hline Overall & $1171(38.2)$ & $20(48.8)$ & $58(44.6)$ & $667(34.5)$ & $271(45.2)$ & $155(50.3)$ \\
\hline$P$ & $<0.001$ & - & - & $<0.001$ & $<0.001$ & 0.011 \\
\hline
\end{tabular}

reliable. However, a few patients diagnosed with AIDS were not included in this study as they did not receive ART for traditional and personal reasons.

The study indicated that average CD4 cell counts increased over time for all age groups, education groups, and sexual transmission route groups. The greatest increase was observed in those aged 25-29 years, those infected through homosexual transmission, and those with $\geq 13$ years of education. Simultaneously, the frequency of CD4 cell counts $<200$ decreased significantly over time, particularly among those aged 25-29 years, those infected through homosexual transmission, and those with $\geq 13$ years of education. These findings suggest that the burden of AIDS may increase in Tianjin in the future. It is crucial to address the management of AIDS patients with high CD4 cell countsin order to ensure that therapy is effective. At the same time, education of high-risk populations should begin in high school.

\section{MATERIALS AND METHODS}

\section{Selection of study subjects}

All consecutive newly diagnosed AIDS patients who were treated with ART in the Department of Infection, Tianjin Second People's Hospital from January 2005 to December 2016 were recruited to this study. This hospital is the only hospital designated to treat AIDS patients in Tianjin, China.
The study design and protocol were approved by the ethics committee of Tianjin Second People's Hospital, and a written informed consent was obtained from each participant.

\section{Data collection}

Information on demographic characteristics (including sex, age, and education level) and disease characteristics (including time of AIDS diagnosis, time of ART initiation, and infection route)were collected. Information related to treatment with ART was also recorded during the study period. Moreover, CD4 cell counts and viral load on admission and at follow-up visits were measured.

\section{Categorization of age, education level, transmission route, and study period}

Age was categorized into eight groups: $<20$ years, 20-24 years, 25-29 years, 30-34 years, 35-39 years, $40-44$ years, $45-49$ years, and $\geq 50$ years. Education was categorized into four groups according to the number of years of education: $<6$ years, 7-9 years, 10-12 years, and $\geq 13$ years. Transmission route was categorized into five groups according to patient self-reporting; categories included transfusion/blood donation, intravenous drug use(IDU), homosexual transmission, heterosexual transmission, and unknown. The study period began 
Table 4: Trends in levels of CD4 of AIDS by education levels during 2005 to 2016 in Tianjin, China (years)

\begin{tabular}{|c|c|c|c|c|c|}
\hline Year & Total & $\leq 6$ years & 7 9years & 10 12years & $\geq 13$ years \\
\hline \multicolumn{6}{|c|}{$\mathrm{CD} 4$, counts $/ \mu \mathrm{L}$, means $(\mathrm{SD})$ : } \\
\hline$<2011$ & $171.12(7.95)$ & $145.54(9.51)$ & $182.85(16.84)$ & $216.87(26.45)$ & $191.47(16.92)$ \\
\hline 2011 & $182.22(8.51)$ & $194.52(19.07)$ & $158.38(18.11)$ & $192.22(17.63)$ & $183.67(13.44)$ \\
\hline 2012 & $196.12(7.61)$ & $176.38(14.12)$ & $201.96(16.61)$ & $192.95(17.44)$ & $206.94(12.74)$ \\
\hline 2013 & $205.56(7.11)$ & $222.51(14.52)$ & $175.35(14.26)$ & $197.98(13.85)$ & $219.39(13.62)$ \\
\hline 2014 & $256.61(6.70)$ & $236.19(13.70)$ & $250.90(15.78)$ & $257.81(16.82)$ & $269.34(9.91)$ \\
\hline 2015 & $275.78(6.22)$ & $227.79(16.51)$ & $264.31(13.91)$ & $295.36(12.44)$ & $285.63(9.56)$ \\
\hline 2016 & $303.28(7.18)$ & $231.42(19.02)$ & $302.76(17.22)$ & $310.56(15.85)$ & $320.24(10.10)$ \\
\hline Overall & $251.68(3.04)$ & $207.34(6.03)$ & $242.97(6.94)$ & $261.25(6.68)$ & $273.74(4.89)$ \\
\hline$P$ & $<0.001$ & $<0.001$ & $<0.001$ & $<0.001$ & $<0.001$ \\
\hline \multicolumn{6}{|c|}{ Proportion of CD $4<200$ counts $/ \mu \mathrm{L}$ : } \\
\hline$<2011$ & $125(58.4)$ & $5(35.7)$ & $45(71.4)$ & $38(50.0)$ & $37(60.7)$ \\
\hline 2011 & $105(51.5)$ & $7(53.8)$ & $37(60.7)$ & $28(49.1)$ & $33(45.2)$ \\
\hline 2012 & $125(46.8)$ & $3(50.0)$ & $32(48.5)$ & $43(51.2)$ & $47(42.3)$ \\
\hline 2013 & $139(43.6)$ & $4(26.7)$ & $42(55.3)$ & $48(45.3)$ & $45(36.7)$ \\
\hline 2014 & $213(36.9)$ & $14(50.0)$ & $53(40.8)$ & $58(39.5)$ & $88(32.4)$ \\
\hline 2015 & $240(32.2)$ & $19(59.4)$ & $65(39.2)$ & $58(26.9)$ & $98(29.6)$ \\
\hline 2016 & $224(30.4)$ & $14(48.3)$ & $49(32.2)$ & $62(33.7)$ & 99 (26.7) \\
\hline Overall & $1171(38.2)$ & $66(48.2)$ & $323(45.2)$ & $335(38.5)$ & $447(33.3)$ \\
\hline$P$ & $<0.001$ & 0.318 & $<0.001$ & $<0.001$ & $<0.001$ \\
\hline
\end{tabular}

in2005, but the years prior to 2011 were combined due to a limited number of AIDS cases from 2005 to 2010. Thus, trends in the epidemiology of AIDS were analyzed according to before 2011, 2011, 2012, 2013, 2014, 2015, and 2016.

\section{CD4 cell counts}

CD4 cell counts were categorized into four groups for analysis according to CD4 cell counts at baseline. The CD4 normal group was defined as CD4 cell count $\geq 500$, mild suppression was defined as CD4 cell count 350-499, moderate suppression was defined as CD4 cell count 200-349, and severe suppression was defined as CD4 cell count $<200$.

\section{Statistical analysis}

Trends in CD4 cell counts were assessed among all patients with AIDS according to two variables: mean CD4 cell count at baseline and frequency of severe suppression. Age is presented as means with standard deviations, and was compared between men and women using the
Student $T$-test. The normality of continuous variables was determined using the one-sample Kolmogorov-Smirnov test. Continuous variables with normal distributions (e.g., age) are presented as means with standard deviations and were compared between men and women using an independent samples $t$-test. Non-normal variables (e.g., CD4 cell count) are presented as medians (interquartile ranges), and differences between groups were compared by the Mann-Whitney U test for two groups and by the Kruskal-Wallis test for $>2$ groups. Categorical variables are presented as numbers of cases (rates) and were compared between groups using the chi-squared test for trends. All statistical analyses were performed using SPSS version 19.0 (SPSS Inc., Chicago, IL), and a two-tailed $P$ value $<0.05$ indicated statistical significance.

\section{Author contributions}

$\mathrm{PM}, \mathrm{XN}$, and $\mathrm{WL}$ were involved in conception and design, and critical review for this article. $\mathrm{XN}$ and JW were involved in data analysis for this article. JQ was involved in manuscript drafting. JQ, PM, LG, DZ, AY, CQ, LL, FY, YW, WY and YG were involved in data 
collection, case diagnosis and confirmation for this article. All authors reviewed the manuscript.

\section{ACKNOWLEDGMENTS}

We thank all participants for their valuable efforts.

\section{CONFLICTS OF INTEREST}

None.

\section{GRANT SUPPORT}

This study was funded by the Tianjin Health and Family Planning Commission of Science and Technology Fund Key Projects (contract: 2014KR03).

\section{REFERENCES}

1. Murray CJ, Ortblad KF, Guinovart C, Lim SS, Wolock TM, Roberts DA, Dansereau EA, Graetz N, Barber RM, Brown JC, Wang H, Duber HC, Naghavi M. Global Regional, and national incidence and mortality for HIV, tuberculosis, and malaria during 1990-2013: a systematic analysis for the Global Burden of Disease Study 2013. Lancet. 2014; 384:1005-70.

2. Ministry of Health of the People's Republic of China. China Public Health Statistics Yearbook 2012. Beijing: Peking Union Medical College Press; 2013

3. Ledergerber B, Lundgren JD, Walker AS, Sabin C, Justice A, Reiss P, Mussini C, Wit F, d'Arminio Monforte A, Weber R, Fusco G, Staszewski S, Law M, et al. Predictors of trend in CD4-positive T-cell count and mortality among HIV1 -infected individualswith virological failure to all three antiretroviral-drug classes. Lancet. 2004; 364:51-62.

4. Langford SE, Ananworanich J, Cooper DA. Predictors of diseaseprogression in HIV infection: a review. AIDS Res Ther. 2007; 4:11.

5. Hoffman J, van Griensven J, Colebunders R, McKellar M. Role of the CD4 count in HIVmanagement. HIV Ther. 2010; 4: 27-39.

6. Egger M, May M, Chêne G, Phillips AN, Ledergerber B, Dabis F, Costagliola D, D'Arminio Monforte A, de Wolf F, Reiss P, Lundgren JD, Justice AC, Staszewski S, et al, and ART Cohort Collaboration. Prognosis of HIV-1infectedpatients starting highly active antiretroviral therapy: a collaborativeanalysis of prospective studies. Lancet. 2002; 360: 119-29.

7. Lundgren JD, Mocroft A, Gatell JM, Ledergerber B, D'Arminio Monforte A, Hermans P, Goebel FD, Blaxhult A, Kirk O, Phillips AN, and EuroSIDA Study Group. A clinically prognosticscoring system for patients receiving highly active antiretroviraltherapy: results from the EuroSIDA study. J Infect Dis. 2002; 185:178-87.
8. WHO; UNAIDS; UNICEF. Towards universal access, Scaling uppriority HIV/AIDS interventions in the health sector. WHO. 2010.

9. Gilks CF, Crowley S, Ekpini R, Gove S, Perriens J, Souteyrand Y, Sutherland D, Vitoria M, Guerma T, De Cock K. The WHO public-health approach to antiretroviral treatment againstHIV in resource-limited settings. Lancet. 2006; 368:505-10.

10. Ivers LC, Kendrick D, Doucette K. Efficacy of antiretroviral therapy programsin resource-poor settings: a meta-analysis of the published literature. ClinInfect Dis. 2005; 41:217-24.

11. Hoffman RM, Jamieson BD, Bosch RJ, Currier J, Kitchen CM, Schmid I, Zhu Y, Bennett K, Mitsuyasu R. Baseline immune phenotypes and $\mathrm{CD} 4+\mathrm{T}$ lymphocyte responses to antiretroviraltherapy in younger versus older HIV-infected individuals. J Clin Immunol. 2011; 31: 873-881.

12. Gupta S, Granich R, Suthar AB, Smyth C, Baggaley R, Sculier D, Date A, Desai MA, Lule F, Raizes E, Blanc L, Hirnschall G. Global policy review ofantiretroviral therapy eligibility criteria for treatment and prevention ofHIV and tuberculosis in adults, pregnant women, and serodiscordantcouples. J Acquir Immune Defic Syndr. 2013; 62:e87-e97.

13. World Health Organisation. Consolidated Guidelines for the Use ofAntiretroviral Drugs for Treating and Preventing HIV Infection.Reccomendations for a Public Health Approach. Geneva, Switzerland:World Health Organisation; 2013.

14. Lundgren JD, Babiker AG, Gordin F, Emery S, Grund B, Sharma S, Avihingsanon A, Cooper DA, Fätkenheuer G, Llibre JM, Molina JM, Munderi P, Schechter M, et al, and INSIGHT START Study Group. Initiation of antiretroviraltherapy in early Asymptomatic HIV infection. N Engl J Med. 2015; 373:795-807.

15. Danel C, Moh R, Gabillard D, Badje A, Le Carrou J, Ouassa T, Ouattara E, Anzian A, Ntakpé JB, Minga A, Kouame GM, Bouhoussou F, Emieme A, et al, and TEMPRANO ANRS 12136 Study Group. A trial of early antiretrovirals andIsoniazid preventive therapy in Africa. N Engl J Med. 2015; 373:808-22.

16. World Health Organization. Guideline on When to Start AntiretroviralTherapy and on Pre-exposure Prophylaxis for HIV. Geneva, Switzerland:World Health Organization; 2015.

17. Goldman JD, Cantrell RA, Mulenga LB, Tambatamba BC, Reid SE, Levy JW, Limbada M, Taylor A, Saag MS, Vermund SH, Stringer JS, Chi BH. Simple adherenceassessments to predict virologic failure among HIV-infected adults withdiscordant immunologic and clinical responses to antiretroviral therapy.AIDS Res Hum Retroviruses. 2008; 24:1031-5.

18. Glass TR, Rotger M, Telenti A, Decosterd L, Csajka C, Bucher HC, Günthard HF, Rickenbach M, Nicca D, Hirschel B, Bernasconi E, Wandeler G, Battegay M, Marzolini C, and Swiss HIV Cohort Study. Determinants of sustained viralsuppression in HIV-infected patients with 
self-reported poor adherence toantiretroviral therapy. PLoS One. 2012; 7:e29186.

19. Tang H, Mao Y, Shi CX, Han J, Wang L, Xu J, Qin Q, Detels $\mathrm{R}, \mathrm{Wu} \mathrm{Z}$. Baseline CD4 cell counts of newly diagnosed HIV cases in China: 2006-2012. PLoS One. 2014; 9:e96098.

20. Aparecida de Assis Patroclo M, de Andrade Medronho R. [Evolution of CD4+ T-cell count among AIDS patients in socially unequal contexts]. [Article in Portuguese]. Cad Saude Publica. 2007; 23:1955-63.

21. Lignani L Jr, Greco DB, Carneiro M. [Assessment of the compliance to antiretroviral drugs among HIV/AIDS patients]. [Article in Portuguese]. Rev Saude Publica. 2001; 35:495-501.

22. Kalichman SC, Ramachandran B, Catz S. Adherence to combinationantiretroviral therapies in HIV patients of low health literacy. J Gen Intern med. 1999; 14: 267-73.

23. Diabate S, Alary M, Koffi CK. Determinants of adherence to highlyactive antiretroviral therapy among HIV-1-infected patients in Coted'Ivoire. AIDS. 2007; 21:1799-803.

24. Byakika-Tusiime J, Polley EC, Oyugi JH, Bangsberg DR. Free HIV antiretroviraltherapy enhances adherence among individuals on stable treatment:implications for potential shortfalls in free antiretroviral therapy. PLoSOne. 2013; 8:e70375.

25. Maqutu D, Zewotir T, North D, Naidoo K, Grobler A. Factors affecting first-monthadherence to antiretroviral therapy among HIV-positive adults in SouthAfrica. Afr J AIDS Res. 2010; 9:117-124.

26. Moore DM, Zhang W, Yip B, Genebat M, Lima VD, Montaner JS, Hogg RS. Non-medically supervised treatmentinterruptions among participants in a universally accessible antiretroviraltherapy programme. HIV Med. 2010; 11:299-307.

27. Saha R, Saha I, Sarkar AP, Das DK, Misra R, Bhattacharya $\mathrm{K}$, Roy RN, Bhattacharya A. Adherence to highly active antiretroviraltherapy in a tertiary care hospital in West Bengal, India. Singapore Med J. 2014; 55:92-98.

28. Sarna A, Pujari S, Sengar AK, Garg R, Gupta I, Dam J. Adherence to antiretroviral therapy \& its determinants amongst HIV patients in India. Indian J Med Res. 2008; 127:28-36.

29. Pasternak AO, de Bruin M, Bakker M, Berkhout B, Prins JM. High Current CD4+ T Cell Count Predicts Suboptimal Adherence to Antiretroviral Therapy. PLoS One. 2015; 10:e0140791.

30. Denison JA, Koole O, Tsui S, Menten J, Torpey K, van Praag E, Mukadi YD, Colebunders R, Auld AF, Agolory S, Kaplan JE, Mulenga M, Kwesigabo GP. Incomplete adherence amongtreatment-experienced adults on antiretroviral therapy in Tanzania, Ugandaand Zambia. AIDS. 2015; 29:361-71.

31. Zhu J, Paul WE. CD4 T cells: fates, functions, and faults. Blood. 2008; 112:1557-69.

32. Zhu J, Yamane H, Paul WE. Differentiation of effector CD4 T cell populations (*). Annu Rev Immunol. 2010; 28:445-89.

33. Moir S, Chun TW, Fauci AS. Pathogenic mechanisms of HIV disease. Annu Rev Pathol. 2011; 6:223-48.
34. Maartens G, Celum C, Lewin SR. HIV infection: epidemiology, pathogenesis, treatment, and prevention. Lancet. 2014; 384:258-71.

35. Stevenson M. HIV-1 pathogenesis. Nat Med. 2003; 9:853-60.

36. Levy JA. HIV pathogenesis and long-term survival. AIDS. 1993; 7:1401-10.

37. Jacobson LP, Phair JP, Yamashita TE. Virologic and immunologicresponse to highly active antiretroviral therapy. Curr HIV/AIDS Rep. 2004; 1:74-81.

38. Takuva S, Maskew M, Brennan AT, Long L, Sanne I, Fox MP. Poor CD4recovery and risk of subsequent progression to AIDS or death despite viralsuppression in a South African cohort. J Int AIDS Soc. 2014; 17:18651.

39. Taiwo BO, Li X, Palella F, Jacobson LP, Margolick JB, Detels R, Rinaldo CR, Phair JP.Higher risk of AIDS or death in patients with lower CD4 cell counts after virally suppressive HAART. HIV Med. 2009; 10:657-60.

40. Biadgilign S, Reda AA, Digafe T. Predictors of mortality among HIVinfected patients taking antiretroviral treatment in Ethiopia: a retrospectivecohort study. AIDS Res Ther. 2012; 9: 15.

41. Gilson RJ, Man SL, Copas A, Rider A, Forsyth S, Hill T, Bansi L, Porter K, Gazzard B, Orkin C, Pillay D, Schwenk A, Johnson M, et al, and UK Collaborative HIV Cohort Study Group. Discordant responses on starting highly active antiretroviral therapy: suboptimal CD4 increases despite early viral suppression in the UK Collaborative HIV Cohort (UK CHIC) Study. HIV Med. 2010; 11:152-60.

42. Chi BH, Giganti M, Mulenga PL, Limbada M, Reid SE, Mutale W, Stringer JS. CD4response and subsequent risk of death among patients on antiretroviraltherapy in Lusaka, Zambia. J Acquir Immune Defic Syndr. 2009; 52:125-31.

43. Zoufaly A, an der Heiden M, Kollan C, Bogner JR, Fätkenheuer G, Wasmuth JC, Stoll M, Hamouda O, van Lunzen J, and ClinSurv Study Group. Clinical outcome of HIV-infected patients with discordant virologicaland immunological response to antiretroviral therapy. J Infect Dis. 2011; 203:364-71.

44. Kim MJ, Chang HH, Kim SI, Kim YJ, Park DW, Kang C, Kee MK, Choi JY, Kim SM, Choi BY, Kim WJ, Kim JM, Choi JY, et al, and Korea HIV/AIDS Cohort Study.Trend of CD4+ Cell Counts at Diagnosis and Initiation of Highly Active Antiretroviral Therapy (HAART): Korea HIV/AIDS Cohort Study, 1992-2015. Infect Chemother. 2017; 49:101-8.

45. Verweel G, van Rossum AM, Hartwig NG, Wolfs TFW, Scherpbier HJ, de Groot R.Treatment with highly active antiretroviral therapy in HumanImmunodeficiency Virus Type 1-infected children is associated with a sustainedeffect on growth. Pediatrics. 2002; 109: e25.

46. Silva M, Skolnik PR, Gorbach SL, Spiegelman D, Wilson IB, Fernández-DiFranco MG, Knox TA. Theeffect of protease inhibitors on weight and body composition in HIVinfectedpatients. AIDS. 1998; 12: 1645-51. 